\title{
Dietary toxicity of metals in aquatic animals: Recent studies and perspectives
}

\author{
WANG Wen-Xiong \\ Division of Life Science, The Hong Kong University of Science and Technology, Clearwater Bay, Kowloon, Hong Kong, China
}

Received March 13, 2012; accepted May 25, 2012; published online September 6, 2012

\begin{abstract}
Over the past decade, the quantitative recognition of the significance of dietary exposure in the overall bioaccumulation of metals in aquatic animals has been an area of major progress in metal ecotoxicology. In several major groups of marine animals such as predators and deposit-feeding animals, diet (food) is the predominant source for metal accumulation. The importance of trophic transfer raises very fundamental questions about its toxicity to aquatic animals and in setting water quality standards which go beyond waterborne metal exposure. Ten years of research on the dietary toxicity of metals in several groups of aquatic animals, including zooplankton and fish, is reviewed. It is suggested the future studies should attempt to incorporate the dosage rate or the dietary influx rate in the design of toxicology experiments to facilitate inter-comparison of the results of different studies.
\end{abstract}

metals, dietary toxicity, zooplankton, fish, water quality criteria, exposure

Citation: Wang W X. Dietary toxicity of metals in aquatic animals: Recent studies and perspectives. Chin Sci Bull, 2013, 58: 203-213, doi: 10.1007/s11434012-5413-7

For any aquatic animal, there are basically two routes for metal exposure: dietary exposure (trophic transfer) and dissolved exposure. Exposure to metals has been a fundamental question in ecotoxicology for aquatic organisms. In order to understand and predict the toxicity of metals, one must first understand the exposure route in natural conditions. In fact, without that knowledge, any toxicity testing can be considered simply a trial. For humans we may readily estimate the sources and potential routes of intake, but it is very difficult to estimate and compare the exposure routes for aquatic animals. Many studies have simply assumed that metals are accumulated by aquatic animals primarily from the dissolved phase, and water quality criteria established for the protection of aquatic organisms have been based on toxicity testing conducted with dissolved metals. In the 1970s and 1980s some experiments were designed specifically to separate the exposure routes of metals in aquatic animals, but it was widely assumed that the significance of dietary exposure could only be considered exceptional instead of a

email: wwang@ust.hk general rule. This was based the memory of Minamata disease which 'naturally' implied that $\mathrm{Hg}$ was accumulated through dietary exposure.

In the 1990 s evidence emerged that the water quality criteria established for some metals were insufficient to protect aquatic organisms [1]. During this period methodologies were developed to measure the essential biokinetic parameters [2-5] in different aquatic animals. One of the main parameters is the efficiency of dietary assimilation (AE). Kinetics plays a central role in the concepts and measurement of dietary AE. The development of the pulse-chase methodology coupled with radiotracer techniques allowed quantification of the AEs of different metals in many aquatic animals. Such AE measurements certainly provide a useful way to compare and quantify the bioavailability of dietary metals.

Exposure to metals depends on their relative flux from the dissolved phase and the dietary phase. To properly delineate the exposure pathways it is absolutely necessary to compare the relative flux from both pathways. The development of biokinetic models in the 1990s provided a realistic 
way to separate the exposure by directly comparing a metal's relative fluxes. Such modeling studies under diverse environmental conditions quantitatively assessed exposures and demonstrated that as a general rule, dietary exposure is a significant exposure route for diverse aquatic animals. Indeed, dietary exposure is almost the only source for metal accumulation in marine predators such as gastropods and fish. It has been shown that these predators often have a very low dissolved uptake rate constant, despite the fact that their feeding activity is also low. In marine suspension feeders such as the bivalves and copepods the relative importance of different exposure routes is more variable. Given the importance of dietary exposure, it should certainly be considered in metal toxicology studies [6].

A natural question is then whether these dietary metals have any toxicity for aquatic animals, and if so, whether the toxicity is comparable to that observed from aqueous exposure under comparable dosage conditions. Another question is the toxicity's application in setting water quality criteria. If the toxicity of dietary metals cannot be ignored, there will certainly be a need to revise water quality criteria to incorporate such exposure. The Society of Environmental Toxicology and Chemistry (SETAC) organized a Pelleston workshop in 2002 to review the then-status of studies related to the dietary toxicity of metals in aquatic systems, and a book on the toxicity of diet-borne metals to aquatic organisms was subsequently published in 2005 [7]. There have since been many studies examining the dietary toxicity of metals for different aquatic animals (particularly the zooplankton cladocerans and fish), but progress has been slower than anticipated due to major obstacles such as uncertainly about the realism of toxicity testing using contaminated diets.

This review will mainly summarize the studies conducted after 2002 on the dietary toxicity of metals for zooplankton and predators such as gastropods and fish. Earlier reviews on the dietary toxicity studies can be found in Meyer et al. [7]. It will also discuss some major considerations and perspectives in realistic toxicity testing of diet-borne metals.

\section{Dietary toxicity of metals to zooplankton}

Studies on the dietary toxicity of metals with zooplankton have mainly focused on the freshwater cladocerans and the marine copepods. Interest in these zooplankton results from their importance in toxicity testing as well as some earlier evidence suggesting that dietary metals are more toxic for such organisms than waterborne metals [8,9]. A typical experiment would involve spiking the waterborne metals to phytoplankton as food for the zooplankton. The animals are exposed to the metal contaminated food for a period of time (chronic exposure), followed by the measurement of different endpoints such as their survival, growth and reproduction, in some cases coupled with measurements of metal accumulation in the animals. The results are then compared with those determined under similar conditions for the waterborne metals. It is important to recognize, however, that there are significant challenges in conducting such tests with dietary metals, such as the release of metals from the contaminated algae into the water during the exposure period and the decrease of food concentrations caused by the feeding, which in turn can further facilitate the release of metals from the food particles into the water [10,11]. Another factor that needs to be considered is any nutritional change in the algae due to metal exposure (i.e., indirect effects), which may also affect the biological endpoints in the animals. Evens et al. [12] have recently developed a technique to produce metal-contaminated liposomes as an alternative delivery system for dietary metals. The liposomes are not vulnerable to metal-induced shifts in nutrient quality and can be mixed with uncontaminated algae at different ratios to produce a diet with different metal concentrations. However, the bioavailability of metals associated with the liposomes may be different from that of food-borne metals.

Earlier studies by Hook and Fisher [8] examined the toxicity of metals in the marine copepods Acartia hudsonica and Acartia tonsa feeding on the diatom Thalassiosira pseudonana with a $\mathrm{Hg}$ concentration of $7 \mu \mathrm{g} / \mathrm{g}$ and a $\mathrm{Cd}$ concentration of $7.1 \mu \mathrm{g} / \mathrm{g}$ for $4 \mathrm{~h}$. The algae had previously been exposed to $0.21 \mu \mathrm{g} / \mathrm{L} \mathrm{Hg}$ or $0.56 \mu \mathrm{g} / \mathrm{L} \mathrm{Cd}$. The calculated total copepod body burden increased 9 times for $\mathrm{Hg}$ and 2 times for $\mathrm{Cd}$, and egg production decreased by $50 \%$. Hatching rate, ovarian development and egg protein content all decreased following the dietary exposure. One proposed cause was vitellogenesis due to the deposition of metals in internal tissues after dietary exposure. In another study, Hook and Fisher [9] found that reproductive success decreased by more than $50 \%$ when the algae were exposed to only $0.11 \mu \mathrm{g} / \mathrm{L}$ of $\mathrm{Ag}$ using the freshwater copepod Simocephalus sp. and $0.055 \mu \mathrm{g} / \mathrm{L}$ of $\mathrm{Ag}$ using the cladocerans. These concentrations were about 200 times (for the freshwater cladocerans) and 400 times lower than the toxic concentrations of dissolved Ag. Again, Ag may depress egg production by reducing yolk protein deposition and ovarian development. In a subsequent study, Hook and Fisher [13] compared the sublethal toxicity of dietary $\mathrm{Ag}, \mathrm{Cd}, \mathrm{Hg}, \mathrm{Mn}$, and $\mathrm{Zn}$ for marine copepods with waterborne metals following a 4-hour feeding on metal-contaminated phytoplankton food and coupled with the calculation of metal concentrations in the copepod tissue. Depressed egg production was documented when the tissue body concentration of the metals was elevated by 3 times for $\mathrm{Ag}, 9$ times for $\mathrm{Hg}$, doubled for $\mathrm{Cd}$ and or increased by only $5 \%$ for $\mathrm{Zn}$.

Those earlier studies rekindled substantial interest in the dietary toxicity of metals in zooplankton. Bielmyer et al. [14] followed them up with toxicity tests on the marine copepod A. tonsa to assess the effects of dietary metal exposure, but they exposed the copepod to $\mathrm{Ag}, \mathrm{Zn}, \mathrm{Cu}$, or $\mathrm{Ni}$ using T. pseudonana for seven days. Reproduction was again observed to be the most sensitive endpoint and the 
$20 \%$ effect concentrations [EC(20)] corresponding to exposures to $T$. pseudonana (in $\mu \mathrm{g} / \mathrm{L}$ ) were 0.64 for $\mathrm{Ag}, 0.3$ for $\mathrm{Zn}, 1.2$ for $\mathrm{Cu}$, and 2.4 for $\mathrm{Ni}$. These concentrations corresponded to concentrations in the algae of 5.44, 0.55, 22.3, and $15.3 \mu \mathrm{g} / \mathrm{g}$ for $\mathrm{Ag}, \mathrm{Zn}, \mathrm{Cu}$, and $\mathrm{Ni}$, respectively. These effective concentrations were well below the current criteria of $3,86,3$, and $8.3 \mu \mathrm{g} / \mathrm{L}$ for $\mathrm{Ag}, \mathrm{Zn}, \mathrm{Cu}$, and $\mathrm{Ni}$, respectively. One surprising result from their study was the extraordinary dietary toxicity of $\mathrm{Zn}$ for the copepods. It is still not clear why copepods are so sensitive to dietary $\mathrm{Zn}$.

In a more recent study, the chronic reproductive toxicity of $\mathrm{Cu}$ was evaluated in A. tonsa following 6 days of exposure to different combinations of $\mathrm{Cu}$ concentration, salinity $(5,15$, and $30 \mathrm{ppt})$, and routes of exposure (waterborne, waterborne plus diet-borne, and diet-borne) [15]. The EC50 values for egg production after waterborne exposure were 9.9, 36.8, and $48.8 \mu \mathrm{g} / \mathrm{L}$ at salinities of 5,15 , and $30 \mathrm{ppt}$, respectively, and they were significantly higher (40.1, 63.7, and $109.9 \mu \mathrm{g} / \mathrm{L}$, respectively) for waterborne plus diet-borne exposure. After diet-borne exposure alone, an approximate
$40 \%$ decrease in egg production was observed, independent of the $\mathrm{Cu}$ concentration and water salinity tested.

Dietary toxicity has been extensively tested with freshwater cladocerans such as Daphnia magna, and most of these studies have focused on $\mathrm{Cu}, \mathrm{Zn}$, and $\mathrm{Cd}$. Table 1 also summarizes those recent studies, and it is obvious that there are significant differences among them. Among the several metals studied so far, $\mathrm{Ag}$ and $\mathrm{Cd}$ have displayed the greatest toxicity, whereas the toxicity of $\mathrm{Cu}$ and $\mathrm{Zn}$ has been less obvious, probably because these two metals are essential to the animals and their accumulation may be metabolically regulated.

De Schamphelaere et al. [16] investigated the potential toxicity of dietary $\mathrm{Cu}$ to $D$. magna feeding on the green alga Pseudokircheneriella subcapitata previously exposed for 3 days to different $\mathrm{Cu}$ concentrations spanning 30 to 1100 $\mu \mathrm{g} / \mathrm{g}$. The biological endpoints measured were growth, reproduction, and $\mathrm{Cu}$ accumulation after 21 days of chronic exposure. Dietary $\mathrm{Cu}$ did not cause toxicity, nor did it alter the 21-d effect concentrations based on waterborne $\mathrm{Cu}$.

Table 1 Studies on dietary metal toxicity using zooplankton after $2002^{\text {a) }}$

\begin{tabular}{|c|c|c|c|}
\hline & Testing conditions & Results & References \\
\hline \multicolumn{4}{|l|}{ Copepods } \\
\hline Acartia tonsa & $\begin{array}{l}\text { Food: diatom Thalassiosina pseudonana, } 7 \mathrm{~d} \text { feeding at } \\
2 \times 10^{5} / \mathrm{mL} \text {, measure egg production. }\end{array}$ & $\begin{array}{l}\text { LOEC concentration } \\
\mathrm{Ag}: 120 \mu \mathrm{g} / \mathrm{g}(\text { exposed at } 5.50 \mu \mathrm{g} / \mathrm{L}) \\
\mathrm{Cu}: 31.9 \mu \mathrm{g} / \mathrm{g}(\text { exposed at } 1.50 \mu \mathrm{g} / \mathrm{L}) \\
\mathrm{Zn}: 3.05 \mu \mathrm{g} / \mathrm{g}(\text { exposed at } 0.40 \mu \mathrm{g} / \mathrm{L}) \\
\mathrm{Ni}: 58.1 \mu \mathrm{g} / \mathrm{g}(\text { exposed at } 7.60 \mu \mathrm{g} / \mathrm{L})\end{array}$ & [14] \\
\hline $\begin{array}{l}\text { Daphnia magna } \\
\text { Ag }\end{array}$ & $\begin{array}{l}\text { Food: Chlamydomonas reinhardtii, exposed at } 0.1-10 \mu \mathrm{g} \\
(\mathrm{Ag}) / \mathrm{L}\left(\mathrm{AgNO}_{3}\right) \text { to give } 1.0-134.1 \mu \mathrm{g}(\mathrm{Ag}) / \mathrm{g} \mathrm{dw}, 21 \mathrm{~d} \\
\text { chronic exposure. Measure survival, body length, number } \\
\text { of neonates and } \mathrm{Ag} \text { bioaccumulation. }\end{array}$ & $\begin{array}{l}\text { Reproduction and time to first brood reduced by } 40 \% \\
\text { at } 1.0 \mu \mathrm{g} \mathrm{Ag} / \mathrm{g} \mathrm{dw} \text { (or } 0.1 \mu \mathrm{g} \mathrm{Ag} / \mathrm{L} \text { in water). }\end{array}$ & [25] \\
\hline $\begin{array}{l}\text { Ceriodaphnia dubia } \\
\mathrm{Cd}\end{array}$ & $\begin{array}{l}\text { Food: Pseudokirchneriella subcapitata exposed at 5.2-61 } \\
\mu \mathrm{g} / \mathrm{L} \text { to give } 0.02-5.60 \mathrm{Cd} \mu \mathrm{g} / \mathrm{g} \mathrm{dw}, 7 \mathrm{~d} \text { exposure. }\end{array}$ & $\begin{array}{l}\text { Survival LOEC: } 3.1 \mu \mathrm{g} / \mathrm{g} \text {. } \\
\text { Feeding LOEC: } 3.1 \mu \mathrm{g} / \mathrm{g} . \\
\text { Reproduction LOEC: } 0.56 \mu \mathrm{g} / \mathrm{g} \text {. }\end{array}$ & {$[21,22]$} \\
\hline $\begin{array}{l}\text { Daphnia magna } \\
\mathrm{Cu}\end{array}$ & $\begin{array}{l}\text { Food: } P . \text { subcapitata exposed at } 0-200 \mu \mathrm{g} / \mathrm{L} \text { to give } \\
28-1520 \mu \mathrm{g}(\mathrm{Cu}) / \mathrm{g} \mathrm{dw}, 21 \mathrm{~d} \text { chronic exposure. }\end{array}$ & $\begin{array}{l}\text { No obvious toxicity for growth or reproduction, but } \\
\text { reproduction increased by } 75 \% \text { at the highest } \mathrm{Cu} \text { die- } \\
\text { tary level. }\end{array}$ & {$[16]$} \\
\hline $\begin{array}{l}\text { Daphnia magna } \\
\mathrm{Cu}\end{array}$ & $\begin{array}{l}\text { Same as above, but } \mathrm{Cu} \text { concentration increased to } 3000 \\
\mu \mathrm{g} / \mathrm{g} \mathrm{dw} \text {. }\end{array}$ & $\begin{array}{l}\text { Growth reduced by } 38 \% \text { and reproduction reduced by } \\
50 \% \text {. }\end{array}$ & [17] \\
\hline $\begin{array}{l}\text { Moina monogolica } \\
\mathrm{Cu}\end{array}$ & $\begin{array}{l}\text { Food: } C \text {. pyrenoidosa exposed at } 0-1000 \mu \mathrm{g} / \mathrm{L} \text { to give } \\
0-10 \mathrm{mg}(\mathrm{Cu}) / \mathrm{g}, 21 \mathrm{~d} \text { chronic exposure. }\end{array}$ & $\begin{array}{l}\text { Reproduction reduced by } 31 \% \text { at } 500 \mu \mathrm{g} / \mathrm{g} \mathrm{Cu} \text {, growth } \\
\text { reduced at } 8 \mathrm{mg} / \mathrm{g}\end{array}$ & [18] \\
\hline $\begin{array}{l}\text { Ceriodaphnia dubia } \\
\mathrm{Cu} \text { and } \mathrm{Ag}\end{array}$ & $\begin{array}{l}\text { Food: contaminated } P . \text { subcapitata or } C . \text { vulgaris for } 4 \mathrm{~h} \text {, } \\
\text { then uncontaminated food, } 7 \mathrm{~d} \text { test. }\end{array}$ & $\begin{array}{l}\text { Reproduction decreased at } \mathrm{Ag} 6.3-48 \mu \mathrm{g}(\mathrm{Ag}) / \mathrm{g} \text { for } \\
P . \text { subcapitata, but for } C \text {. vulgaris at } \mathrm{Ag} \text { concentra- } \\
\text { tion as high as } 800 \mu \mathrm{g} / \mathrm{g} \text {. } \\
\text { No reproduction impairment for daphnids feeding on } \\
\text { either alga at } \mathrm{Cu} \text { concentrations as high as } 1.16 \mathrm{mg} / \mathrm{g} \text {. }\end{array}$ & {$[20]$} \\
\hline $\begin{array}{l}\text { Daphnia magna } \\
\mathrm{Zn}\end{array}$ & $\begin{array}{l}\text { Food: } P . \text { subcapitata exposed at } 0-61 \mu \mathrm{g} / \mathrm{L} \text { to give } \\
130-490 \mu \mathrm{g}(\mathrm{Zn}) / \mathrm{g}, 21 \mathrm{~d} \text { chronic test. }\end{array}$ & Reproduction deceased by $40 \%$ at $320-490 \mu \mathrm{g} / \mathrm{g}$. & [27] \\
\hline
\end{tabular}

a) LOEC: lowest observable effect concentration; dw: dry weight. 
Indeed, an exposure to higher levels of dietary $\mathrm{Cu}$ appeared to be beneficial and caused a $75 \%$ increase in growth and reproduction. To follow up this study, the same laboratory further elevated the $\mathrm{Cu}$ level to $3000 \mu \mathrm{g} / \mathrm{g}$ dry weight (dw) in P. subcapitata [17]. After 21 days of feeding D. magna on this $\mathrm{Cu}$-contaminated food, the average body $\mathrm{Cu}$ accumulation $(325 \mu \mathrm{g}(\mathrm{Cu}) / \mathrm{g} \mathrm{dw})$ was about 30 times higher than in the controls $(12.1 \mu \mathrm{g}(\mathrm{Cu}) / \mathrm{g} \mathrm{dw})$. Growth and reproduction were reduced by $38 \%$ and $50 \%$, respectively, and the brood number was reduced from 4 to 3 . Other reproductive performance such as the second and third broods were significantly delayed by 0.7 and $1.5 \mathrm{~d}$, respectively, and the size of all three broods was reduced by $32 \%$ to $55 \%$ in the $\mathrm{Cu}$-exposed daphnids. At such high dietary $\mathrm{Cu}$ levels reproductive impairment was probably caused by the increased metabolic cost, reduced energy intake, inhibition of vitellogenesis, or direct inhibition of molting.

Using another cladoceran, Moina monogolica, Wang et al. [18] examined the chronic toxicity of dietary $\mathrm{Cu}$. The daphnids were fed green algae Chlorella pyrenoidosa previously exposed for $96 \mathrm{~h}$ to a control and to seven dissolved copper concentrations. Dietary $\mathrm{Cu}$ did not affect the size of the first brood, but brood size decreased significantly in all subsequent broods at algal $\mathrm{Cu}$ concentrations ranging from 44.8 to $817 \mu \mathrm{g} / \mathrm{g}$. Other reproductive endpoints such as total reproduction and net reproductive rate were significantly reduced at all dietary $\mathrm{Cu}$ exposures, and significant reduction of the intrinsic rate of natural increase was found with algae exposed to concentrations $>619 \mu \mathrm{g} / \mathrm{g}$. These results suggest that $M$. monogolica is probably more sensitive to dietary $\mathrm{Cu}$ than $D$. magna. One hypothesis put forward by the authors is that the nutritional content of the algal diet was modified by $\mathrm{Cu}$ exposure, leading to a change in $M$. monogolica's reproduction. In fact, there are clear differences in metal sensitivity among different cladoceran species [19].

Kolts et al. [20] investigated another cladoceran, Ceriodaphnia dubia, by feeding them with Ag- or Cu-contaminated green algae (either P. subcapitata or Chlorella vulgaris). They showed that diet-borne metal did not cause any survival or reproduction effects different from those of the waterborne metal. Additional diet-borne-only toxicity tests were performed by feeding $C$. dubia with metal-contaminated algae for $4 \mathrm{~h}$ following Hook and Fisher's [8] protocol, or standard amounts of metal-contaminated algae and uncontaminated food slurry for the entire three-brood test. In contrast to previous studies, no consistent diet-borne metal toxicity was found in those experiments. The authors suggest that variation in the intracellular partitioning of metals in the algae, inter-laboratory differences in experimental procedures, or selective feeding with $C$. dubia to avoid metal-contaminated algae may account for the different results. This was one of the few studies so far which have documented no dietary influence of $\mathrm{Ag}$ or $\mathrm{Cu}$ on the reproduction of cladocerans.
Sofyan et al. [21] has compared the effects of waterborne and dietary $\mathrm{Cd}$ on the survival, feeding rate, and reproduction of $C$. dubia. One interesting result from this study was that combined waterborne plus dietary exposure resulted in greater toxicity than separate exposures. In a subsequent study [22], they compared Cd uptake from waterborne, dietary, and combined exposure using $C$. dubia. Both feeding and reproduction rates were reduced with all avenues of exposure. Geffard et al. [23] similarly quantified the chronic toxicity of dietary $\mathrm{Cd}$ in terms of the reproduction of $D$. magna. Neonates were successively exposed to dissolved $\mathrm{Cd}$ for $8 \mathrm{~h}$ and then to uncontaminated or contaminated algae for $16 \mathrm{~h}$, repeatedly for $21 \mathrm{~d}$. Dietary $\mathrm{Cd}$ induced deleterious effects on D. magna's reproduction, probably through depression of the feeding rate. Wang et al. [24] subsequently examined the chronic toxicity of dietary $\mathrm{Cd}$ for M. monogolica and compared it with aqueous exposure. The green algae $C$. pyrenoidosa were exposed for four days to sublethal dissolved $\mathrm{Cd}$ over a concentration range of 4.1$70.3 \mu \mathrm{g} / \mathrm{L}$, and then used as food. At the dietary Cd concentrations tested, significant reduction of reproduction was observed in all broods, and the decline in the number of neonates produced increased with each subsequent brood. Such reduced reproduction was documented at the lowest Cd concentration $(4.1 \mu \mathrm{g} / \mathrm{L})$, with a corresponding Cd concentration in the algae of $13 \mu \mathrm{g} / \mathrm{g}$, highlighting that dietary exposure to cadmium may cause sublethal responses.

Zhao and Wang [25] also conducted a 21-d chronic exposure of diet-borne $\mathrm{AgNO}_{3}$ using D. magna and compared the biological endpoints with those of waterbone $\mathrm{AgNO}_{3}$ exposure. The daphnids were observed to be very sensitive to aqueous $\mathrm{Ag}$ exposure, and the survivorship gradually decreased and was only $50 \%$ at the highest concentration $(1.6 \mu \mathrm{g} / \mathrm{L})$ at the end of the exposure. In contrast, Ag content in the diet over the range of 1.0 to $134.1 \mu \mathrm{g} / \mathrm{g} \mathrm{dw}$ led to only $10 \%$ mortality during the exposure. However, reproductive performance was significantly affected by dietary Ag exposure. The total number of neonates produced during the 21-d exposure was reduced by $40 \%$ and the time to the first brood was delayed at an $\mathrm{Ag}$ concentration as low as 0.1 $\mu \mathrm{g} / \mathrm{L}$ in the medium $(1.0 \mu \mathrm{g} / \mathrm{g} \mathrm{dw}$ in the algae and $0.22 \mu \mathrm{g} / \mathrm{g}$ $\mathrm{dw}$ in the daphnids). The average number of neonates per living parent also obviously decreased during dietary Ag$\mathrm{NO}_{3}$ exposure (29-45 neonates compared with an average of 73.6 neonates among the controls). Furthermore, a significant reduction of body length was observed after diet-borne $\mathrm{AgNO}_{3}$ exposure compared to the controls.

Evens et al. [26] investigated the chronic toxicity of dietary Ni for D. magna. The green algae were contaminated with $\mathrm{Ni}$ at concentrations of 33.7-837 $\mu \mathrm{g}(\mathrm{Ni}) / \mathrm{g} \mathrm{dw}$. At a dietary Ni concentrations of 85.6 and $837 \mu \mathrm{g}(\mathrm{Ni}) / \mathrm{g} \mathrm{dw}, D$. magna significantly accumulated diet-borne $\mathrm{Ni}$. The time to the first brood was 0.7 to $1.1 \mathrm{~d}$ earlier than the control animals, and the number of offspring in the first brood was significantly reduced (by $21 \%-33 \%$ ) with all dietary treatments. 
The change in diet quality due to Ni exposure did not affect growth or total reproductive output. To further eliminate the potential influence of nutritional quality on the reproductive performance, Evens et al. [12] prepared liposomes containing $\mathrm{Ni}$ and mixed the particles with uncontaminated green algae at different ratios to result in diets with two different $\mathrm{Ni}$ concentrations. Dietary Ni exposure at $144 \mu \mathrm{g}(\mathrm{Ni}) / \mathrm{g} \mathrm{dw}$. inhibited growth and led to $100 \%$ mortality after 14 days of exposure. The size of the first brood of the Ni-exposed daphnids was also significantly reduced (by 85\%). Compared to the control, the algal ingestion rate increased by $68 \%$ after 6 days of exposure, but then reduced by $80 \%$ after $13 \mathrm{~d}$, which may explain the observed effects of dietary $\mathrm{Ni}$ on later growth and reproduction.

De Schamphelaere et al. [27] investigated the chronic toxicity of dietary $\mathrm{Zn}$ by feeding the daphnids with preexposed green algae (130-490 $\mu \mathrm{g} / \mathrm{g}$ dry weight). During the 21 days of chronic exposure, neither the feeding rate nor somatic growth of $D$. magna was affected, but there was a $40 \%$ decrease in the number of juveniles per adult at the two highest $\mathrm{Zn}$ levels. The mean brood size and the fraction of reproducing parent daphnids were reduced from the second brood. It appears that dietary $\mathrm{Zn}$ specifically affects reproduction in D. magna through accumulation in particular target sites for vitellogenin synthesis. In another study, Canli [28] exposed D. magna neonates to waterborne $\mathrm{Zn}$, dietary $\mathrm{Zn}$, or waterbone+dietary $\mathrm{Zn}$ for $4 \mathrm{~d}$. Dietary $\mathrm{Zn}$ exposure led to significant changes in the animals' energy reserves by increasing their protein levels. Their subsequent tolerance for $\mathrm{Zn}$ also increased following dietary $\mathrm{Zn}$ exposure. A summary of the studies since 2002 on the toxicity of dietary metals to zooplankton is also summarized in Table 1 .

\section{Dietary toxicity of metals to fish}

There have also been many studies on the dietary toxicity of metals to fish. Earlier results have, however, been rather contradictory. For example, exposure to elevated dietary $\mathrm{Cd}$ has been observed to increase mortality rates among rainbow trout [29] and reduce growth rates [30], but there have also been reports of no effect on mortality or growth rates of fish [31-34]. Clearwater et al. [35] reviewed the bioavailability and toxicity of diet-borne copper and zinc to fish. The dietary and waterborne toxicities of metals were compared using a daily dose protocol. For laboratory-prepared diets, diet-borne $\mathrm{Cu}$ toxicity occurred at daily doses above $1 \mu \mathrm{g} \mathrm{g}^{-1}$ (body weight) $\mathrm{d}^{-1}$ for channel catfish (Ictalurus punctatus), 1-15 $\mu \mathrm{g} \mathrm{g}^{-1} \mathrm{~d}^{-1}$ (depending on the life stage) for Atlantic salmon (Salmo salar), and 35-45 $\mu \mathrm{g} \mathrm{g}^{-1} \mathrm{~d}^{-1}$ for rainbow trout (Oncorhynchus mykiss). In contrast, diet-borne Zn toxicity has not yet been demonstrated in rainbow trout or turbot (Scophthalmus maximus) at $\mathrm{Zn}$ doses of $<90 \mu \mathrm{g} \mathrm{g}^{-1} \mathrm{~d}^{-1}$, but daily doses of 9-12 $\mu \mathrm{g} \mathrm{g}^{-1} \mathrm{~d}^{-1}$ in laboratory-prepared diets were toxic to three other species: the carp Cyprinus carpio, Nile tilapia Oreochromis niloticus, and the guppy Poecilia reticulata.

Toxicity experiments with fish generally involve spiking artificial (commercial) diets with the metals directly or exposing prey organisms to a metal solution for a period of time. Other experiments have used naturally contaminated prey, but such experiments are constrained by the availability of contaminated preys as well as the multiple sources of metal contamination.

Several studies using artificial diets have addressed the toxicities of $\mathrm{Ag}, \mathrm{Cd}, \mathrm{Ni}$ and $\mathrm{Cu}$ for different species of marine and freshwater fish. For example, Galvez et al. [36] exposed rainbow trout to Ag (as silver thiosulphate) biologically incorporated into trout meal) at an $\mathrm{Ag}$ concentration of $3.1 \mu \mathrm{g} / \mathrm{g}$. The trout were fed to satiation once daily for 128 d. Dietary silver did not significantly affect their mortality, growth, food consumption or food conversion efficiency, nor their ion regulation, hematology, plasma glucose, metabolism or intestinal $\mathrm{Na} / \mathrm{K}$-ATPase and amylase activities. In this study, the Ag concentrations in the livers reached as high as $20 \mu \mathrm{g} / \mathrm{g}$ on day 36 of the dietary exposure. Ptashynski et al. [37] fed adult lake whitefish (Coregonus clupeaformis) with diets containing $0,10,100$ or $1000 \mu \mathrm{g}$ (Ni)/g for $104 \mathrm{~d}$, and found that dietary Ni did not affect their growth or condition, nor hematological variables such as the concentrations of glucose, hemoglobin and hematocrit. However, there were apparent histopathological lesions in the kidney and liver (such as focal necrosis and altered bile ducts). Other biochemical responses included metallothionein (MT) induction and altered lipid peroxide concentrations, but these were not consistent with the different exposure durations.

Dang and Wang [38] reported feeding the marine grunt Terapon jarbua with a Cd-contaminated diet or exposing them to waterborne $\mathrm{Cd}$ for 4 weeks, followed by measurements of tissue-specific $\mathrm{Cd}$ bioaccumulation and its effects. $\mathrm{Cd}$ accumulation peaked in the fish's livers $(5.0-6.3 \mu \mathrm{g} / \mathrm{g})$, digestive tracts $(0.83-3.16 \mu \mathrm{g} / \mathrm{g})$ and gills $(0.27-2.74 \mu \mathrm{g} / \mathrm{g})$. But biological endpoints including the survival rate, specific growth rate, condition factor, and superoxide dismutase activity were not significantly affected by $\mathrm{Cd}$ exposure, though MT was induced by $\mathrm{Cd}$ exposure and there was a significant change in Cd's subcellular distribution. These results suggest that $\mathrm{Cd}$-induced storage and detoxification in T. jarbua may increase the fish's tolerance to toxic metals. Tan et al. [39] similarly investigated the effects of dietary $\mathrm{Cd}$ on the growth, body composition and several enzymatic activities of juvenile yellow catfish, Pelteobagrus fulvidraco, at four dietary Cd levels: $0.25 \mu \mathrm{g} / \mathrm{g}$ (the control), 4.9, 48.6 and $475 \mu \mathrm{g} / \mathrm{g}$ of diet. After four weeks of exposure, the weight gain, specific growth rate, food intake and protein efficiency ratio tended to decline with increasing dietary $\mathrm{Cd}$ level. In this study, $\mathrm{Cd}$ accumulation was much less responsive 
to dietary $\mathrm{Cd}$, but enzymatic responses such as hepatic alkaline phosphatase, glutathione peroxidase and lactate dehydrogenase activities all increased with increasing dietary $\mathrm{Cd}$ levels.

In a most recent study, Dang et al. [40] exposed the marine juvenile blackhead seabream Acanthopagrus schlegelii to $\mathrm{Cu}$ either in a commercial fish diet or in seawater. One particular feature of their experiment was that the influx rates of $\mathrm{Cu}$ from the waterborne and dietary exposure were comparable, so the responses to the two exposure routes could be directly compared. After 14 or $28 \mathrm{~d}$ of exposure, the condition factor, liver somatic index and specific growth rates, as well as the $\mathrm{Cu}$ concentrations in different tissues (liver, intestine, gill and muscle samples) were quantified. Waterborne $\mathrm{Cu}$ appeared to result in higher mortality than dietary $\mathrm{Cu}$ at a given influx rate, thus influx was not a good predictor of mortality across both exposure pathways though it can explain the $\mathrm{Cu}$ accumulation in the intestine/ liver independent of the exposure route. Interestingly, gill $\mathrm{Cu}$ accumulation clearly accounted for the observed mortality and was not related to the route of exposure, therefore it may be possible to use gill $\mathrm{Cu}$ accumulation as an indicator of long-term $\mathrm{Cu}$ toxicity in marine fish. These results suggest that $\mathrm{Cu}$ accumulation in the gills of marine fish may integrate the dietary and waterborne exposure to predict $\mathrm{Cu}$ toxicity.

Several studies have exposed fish to natural prey previously exposed to different metals. Hansen et al. [41] fed juvenile rainbow trout with live Lumbriculus variegatus cultured in metal-contaminated sediments. Biomarkers measured in that study included individual growth after 14, 28, 42, 56 and 67 days of exposure, coupled with whole-body metal concentrations and histological indicators. There was significant growth inhibition in trout fed the contaminated diets, presumably due to reductions in food conversion efficiency rather than reduced food intake. The growth inhibition was negatively correlated with As levels in trout tissue residues. Histological changes included hepatic necrosis and degenerative alterations in the gall bladder. More recently, Erickson et al. [42] tested the influence of consuming live $L$. variegatus contaminated with $\mathrm{Cu}, \mathrm{Cd}, \mathrm{Pb}$ or $\mathrm{As}$ on the growth and survival of juvenile fish during a 30 day exposure period. There was no effect on the growth and survival of rainbow trout at $130-310 \mu \mathrm{g}(\mathrm{Cu}) / \mathrm{g} \mathrm{dw}$, on fathead minnows (Pimephales promelas) at $90-540 \mu \mathrm{g}(\mathrm{Cd}) / \mathrm{g}$, or on channel catfish (Ictalurus punctatus) at $850-1000 \mu \mathrm{g}(\mathrm{Pb}) / \mathrm{g}$. In contrast, 26-77 $\mu \mathrm{g} / \mathrm{g}$ of As inversely affected the growth of rainbow trout in a dose-dependent manner, possibly due to slower feeding, reduced food conversion efficiency, and digestive effects. In another study, juvenile rainbow trout were exposed for $28 \mathrm{~d}$ to a range of As concentrations in water or/and in a live oligochaete diet [43]. Following feeding on worms that had been exposed to arsenate at 4 or $8 \mathrm{mg}$ (As)/L, the fish displayed significant reductions in growth, but there was no obvious change in fish growth following aqueous exposure except at a very high waterborne arsenate concentrations (16 or $32 \mathrm{mg}(\mathrm{As}) / \mathrm{L})$. The greater toxicity of diet-borne As to rainbow trout compared to waterborne exposure strongly suggests that dietary toxicity may occur in natural environments in which waterborne exposure may not indicate any toxic potential.

Zhang et al. [44] fed juveniles of the juvenile grunt $T$. jarbua with As-contaminated artificial diets at nominal concentrations of 50,150 or $500 \mu \mathrm{g}(\mathrm{As}(\mathrm{III})$ or $\mathrm{As}(\mathrm{V})) / \mathrm{g} \mathrm{dw}$, and their transformation and growth responses were compared to those exposed to $100 \mu \mathrm{g} / \mathrm{L}$ waterborne As(III) or As(V). Within the 10 days exposure period, As bioaccumulation in the fish was very low and not proportional to the inorganic As exposure concentration, and there was no evidence of growth inhibition at those concentrations. Indeed, the low As bioaccumulation in the fish tissues confirms the reported low bioavailability of As to marine fish [45]. Significant biotransformation was however found in the fish following inorganic As dosage. By the end of the exposure, the majority of the As (89\%-97\%) in the fish had been transformed into non-toxic arsenobetaine (AsB). The low toxicity of As in these fish may be due to rapid biotransformation and the development of detoxified strategies such as the binding of As with MT. Subcellular fractionation results also suggest that As was mainly bound with metallothionein-like protein (MTLP), followed in decreasing order of importance by cellular debris, metal-rich granules (MRGs), organelles and heat-denatured proteins (mainly enzymes) after waterborne or dietary exposure.

In a series of studies, the dietary toxicity of metals to zebrafish has been tested from different perspectives. Khan et al. [46] exposed the crustacean Gammarus pulex to 300 $\mu \mathrm{g} / \mathrm{L}$ of $\mathrm{Cd}$ for $13 \mathrm{~d}$, and purified two biological fractions: MTLP and MRG+exoskeleton. Zebrafish were pulse fed with these two fractions and the dietary assimilation efficiency (AE), carcass and gut tissue metal concentrations, as well as gut lipid peroxidative damage measured as malondialdehyde (MIDA) were assessed. Feeding both biological fractions increased the fish's MDA levels, but MRG + exoskeleton produced more oxidative damage than MTLP feeding. In another study, they similarly exposed G. pulex to $11 \mu \mathrm{g} / \mathrm{L}$ of $\mathrm{Cu}$ or $660 \mu \mathrm{g} / \mathrm{L}$ of $\mathrm{Zn}$ for $16 \mathrm{~d}$, and then isolated the MTLP and MRG+exoskeleton fractions. These fractions were imbedded in gelatin and pulse fed to zebrafish as a single meal [47]. There was a significant difference between the retention of the MTLP-Zn (39.0\%) and the MRG+exoskeleton-Zn (17.2\%), but no significant difference was found for $\mathrm{Cu}$. $\mathrm{Zn}$ did not induce a lipid peroxidation response in the intestinal tissue of zebrafish, but dietary $\mathrm{Cu}$ induced lipid peroxidation and the MRG+exoskeleton fraction induced higher MDA levels than the MTLP feed. Both studies thus suggest that the less available fraction (MRG+exoskeleton) may result in a stronger intestinal stress response than the more bioavailable MTLP.

Several other studies have used natural contaminated 
prey to test the dietary toxicity of metals in fish. Boyle et al. [48] examined the toxic effects of metals in zebrafish fed metal-contaminated Nereis diversicolor collected from a metal-impacted estuary for $68 \mathrm{~d}$. Fish fed the metal laden $N$. diversicolor showed reduced reproductive outputs but there was no effect on growth. It appeared that only As was significantly accumulated in the fish's tissues and caused the toxicity. Reproduction is therefore sensitive to exposure to a natural diet contaminated with As, and this exposure route is likely to be of significance to the health of fish populations. The same group later assessed the reproductive performance of zebrafish fed diets supplemented with naturally $\mathrm{Pb}$-enriched $N$. diversicolor at a daily dosage of $1 \%$ (dry weight diet/wet weight fish). Those polychaetes were again collected from a contaminated site (the Gannel estuary in Cornwall, UK) and a control site (the Blackwater estuary in Essex) for $63 \mathrm{~d}$. The estimated daily dietary doses of $\mathrm{Pb}$ were 0.417 and $0.1 \mu \mathrm{g} \mathrm{g}^{-1} \mathrm{~d}^{-1}$ (dry weight feed/wet weight fish) for fish fed $N$. diversicolor from the contaminated and control sites, respectively [49]. Among the metals involved (Ag, As, $\mathrm{Cd}, \mathrm{Cu}, \mathrm{Fe}$ and $\mathrm{Zn}$ ), only the $\mathrm{Ag}$ concentrations were higher for fish fed $N$. diversicolor from the Gannel estuary. Fish fed $\mathrm{Pb}$-enriched worms exhibited no impairment of their incidence of spawning, the number of eggs per breeding pair or the hatch rate of embryos, even though the whole body $\mathrm{Pb}$ burdens of the male fish increased. In another study, zebrafish were fed $N$. diversicolor collected from a $\mathrm{Ag}, \mathrm{Cd}$ and $\mathrm{Cu}$ contaminated site (Restronguet Creek) and a control site (the Blackwater estuary) at 3\% of their wet weight/day for $21 \mathrm{~d}$ [50]. The AEs of $\mathrm{Cd}$ and $\mathrm{Ag}$ and the mRNA expression analysis of metal transporters were then determined. This study showed that metal bioavailability to fish and intestinal uptake were affected during chronic dietary exposure to contaminated worms.

A more recent study fed the marine fish $T$. jurbua with commercial feed supplemented with contaminated natural prey (the polychaete $N$. diversicolor or the clam Scrobicularia plana) collected from metal-impacted estuaries in southwest England [51]. After 21 days of exposure the fish showed differences in mortality between the S. plana and $N$. diversicolor treatments, which was unlikely to have been caused by nutritional differences, since the fish's main food was the artificial diet. Instead, the difference was probably caused by the difference in metal doses between $N$. diversicolor and S. plana. Specifically, $\mathrm{Pb}, \mathrm{Fe}, \mathrm{Cd}$ and $\mathrm{Zn}$ in the field-collected invertebrates were strongly correlated with the observed mortality, suggesting that dietary toxicity may be caused by a mixture of these metals. These results suggest that metals naturally incorporated into invertebrates are of toxicological significance to these fish. Thus, in addition to As identified in earlier study [48], $\mathrm{Pb}, \mathrm{Fe}, \mathrm{Zn}$ and $\mathrm{Cd}$ should also be considered in the ecotoxicological evaluation of invertebrates collected from metal-contaminated estuaries. A summary of the studies since 2002 on the toxicity of dietary metals to fish is also summarized in Table 2.

\section{Dietary toxicity of metals to other aquatic animals}

There have been fewer studies of the dietary toxicity of metals using other aquatic animals. Focusing on amphipods, Besser et al. [52] studied the acute and chronic toxicity of waterborne and dietary $\mathrm{Pb}$ using Hyalella azteca. The amphipods were exposed for 42 days to waterborne $\mathrm{Pb}$ and fed either a control diet or a diet equilibrated with the waterborne $\mathrm{Pb}$ levels. Dietary exposure increased Pb's toxicity to the amphipods. The $50 \%$ lethal concentration for waterborne $\mathrm{Pb}$ decreased from $24 \mu \mathrm{g} / \mathrm{L}$ with the control diet to 16 $\mu \mathrm{g} / \mathrm{L}$ with the contaminated diet, with significant reductions in growth and reproduction at $3.5 \mu \mathrm{g} / \mathrm{L}$.

Ball et al. [53] conducted 4- and 10-week chronic toxicity tests with $H$. azteca fed Cd-contaminated Chlorella. Unlike waterborne $\mathrm{Cd}$ toxicity, growth was a more sensitive toxicological endpoint than survival, with calculated 50\% (EC50) and $25 \%$ (EC25) effect concentrations of $0.6 \mu \mathrm{g} / \mathrm{g}$ and 0.3 $\mu \mathrm{g} / \mathrm{g}$, respectively. These corresponded to EC50 and EC25 for dissolved $\mathrm{Cd}$ at $1.3 \mu \mathrm{g} / \mathrm{L}$ and $0.6 \mu \mathrm{g} / \mathrm{L}$, respectively. Interestingly, there was no bioaccumulation of $\mathrm{Cd}$ in $\mathrm{H}$. azteca fed contaminated food, suggesting that the dietary toxicity of $\mathrm{Cd}$ in the amphipods cannot be predicted simply based on bioaccumulation. Clearly the toxic action may be different between waterborne and diet-borne exposure. Recently, Golding et al. [54] attempted to relate the bioaccumulation of $\mathrm{Cd}$ in amphipods to chronic toxic effects. In that study the amphipods were chronically exposed ( $28 \mathrm{~d}$ ) to a natural periphyton diet (44 to $2900 \mu \mathrm{g}(\mathrm{Cd}) / \mathrm{g}$ ash-free dry mass) and to $\mathrm{Cd}$ in water at 0.35 to $11.2 \mu \mathrm{g} / \mathrm{L}$. Cd bioaccumulation, survival, and growth were measured. Survival as a function of the lethal body concentration of $\mathrm{Cd}(76 \mu \mathrm{g} / \mathrm{g})$ was found to be the most robust endpoint, and dietary $\mathrm{Cd}$ contributed markedly (26\%-90\%) to Cd bioaccumulation in H. azteca.

Cheung et al. [55] fed the rock oyster Saccostrea cucullata or the herbivorous snail Monodonta labio previously exposed to $\mathrm{Cd}$ to the marine predatory whelk Thais clavigera for 4 weeks. There were clear changes in Cd's subcellular distribution in the whelks-its distribution in the MTLP and organelle fractions increased, but it decreased in the MRG fraction. There was no clear evidence of toxicity in the whelks fed different Cd-exposed prey as revealed by various biomarkers at the different biological levels (condition index, lipid peroxidation, and total energy reserve). These results indeed suggest that the Cd's dietary toxicity to predators is low as evolutionary theory would suggest, despite high accumulated $\mathrm{Cd}$ body concentrations. The induction of MT in response to $\mathrm{Cd}$ dietary exposure might be a detoxification mechanism.

The responses of gastropods to dietary metal exposure have also been examined using herbivorous abalones. Huang et al. [56] compared the chronic waterborne and dietary exposure of $\mathrm{Ag}$ and $\mathrm{Cd}$ to the abalone Haliotis diversicolor 
Table 2 Studies on dietary metal toxicity using fish after 2002

\begin{tabular}{|c|c|c|c|}
\hline Fish & Testing conditions & Results & References \\
\hline $\begin{array}{l}\text { Juvenile rainbow trout } \\
\text { Oncorhynchus mykiss }\end{array}$ & $\begin{array}{l}\text { Diet: Lumbriculus variegates exposed to contaminated } \\
\text { sediment, with } 11-129 \mu \mathrm{g}(\mathrm{As}) / \mathrm{g}, 0.2-4.9 \mu \mathrm{g}(\mathrm{Cd}) / \mathrm{g} \text {, } \\
24.3-73.1 \mu \mathrm{g} \mathrm{Cu} / \mathrm{g}, 1.5-226 \mu \mathrm{g}(\mathrm{Pb}) / \mathrm{g}, 338-1334 \mu \mathrm{g} \mathrm{Zn} / \mathrm{g} \text {; } \\
\text { daily feeding rate of } 16 \% \text { of body weight. }\end{array}$ & $\begin{array}{l}\text { Significant reduction in growth, most likely caused } \\
\text { by As in the diets. }\end{array}$ & [41] \\
\hline $\begin{array}{l}\text { Zebrafish } \\
\text { Danio rerio }\end{array}$ & $\begin{array}{l}\text { Diet: natural contaminated Nereis diversicolor, with } 15- \\
140 \mu \mathrm{g}(\mathrm{As}) / \mathrm{g},<2 \mu \mathrm{g}(\mathrm{Cd}) / \mathrm{g}, 16-450 \mu \mathrm{g}(\mathrm{Cu}) / \mathrm{g},<2 \mu \mathrm{g} \\
(\mathrm{Pb}) / \mathrm{g}, 120-320 \mu \mathrm{g}(\mathrm{Zn}) / \mathrm{g} ; 68 \mathrm{~d} \text { feeding at } 3 \% \text { wet } \\
\text { weight daily. }\end{array}$ & $\begin{array}{l}\text { Reduced reproductive output likely caused by As, } \\
\text { but no growth impact. }\end{array}$ & {$[48]$} \\
\hline $\begin{array}{l}\text { Zebrafish } \\
\text { Danio rerio }\end{array}$ & $\begin{array}{l}\text { Diet: natural } N \text {. diversicolor contaminated with } \mathrm{Pb}(1.7- \\
33.4 \mu \mathrm{g} / \mathrm{g}) ; 63 \mathrm{~d} \text { feeding, with daily dietary doses of } \\
0.10-0.417 \mathrm{mg}(\mathrm{Pb}) \mathrm{kg}^{-1} \mathrm{~d}^{-1} \text {. }\end{array}$ & $\begin{array}{l}\text { No impairment of spawning, reproduction rate or } \\
\text { hatch rate of embryoes. }\end{array}$ & [49] \\
\hline $\begin{array}{l}\text { Lake whitefish } \\
\text { (Coregonus } \\
\text { clupeaformis) }\end{array}$ & $\begin{array}{l}\text { Diet: commercial pellets containing } 0,10,100 \text {, and } 1000 \\
\mu \mathrm{g}(\mathrm{Ni}) / \mathrm{g} \text {. Feeding for } 10,31 \text { or } 104 \mathrm{~d} \text { at } 0.5 \% \text { body } \\
\text { weight every alternate day. }\end{array}$ & $\begin{array}{l}\text { No influence on growth or hematology, but histo- } \\
\text { pathological lesions in kidney and liver. }\end{array}$ & [37] \\
\hline $\begin{array}{l}\text { Rainbow trout } \\
\text { (O. mykiss) } \\
\text { Fathead minnow } \\
\text { (Pimephales promelas) } \\
\text { Channel catfish } \\
\text { (Ictalurus punctatus) }\end{array}$ & $\begin{array}{l}\text { Diet: Lumbriculus variegates contaminated with metals: } \\
130-310 \mu \mathrm{g}(\mathrm{Cu}) / \mathrm{g} \text { or } \\
90-540 \mu \mathrm{g}(\mathrm{Cd}) / \mathrm{g} \text { or } \\
850-1000 \mu \mathrm{g}(\mathrm{Pb}) / \mathrm{g} \text { or } \\
26-77 \mu \mathrm{g}(\mathrm{As}) / \mathrm{g} .\end{array}$ & $\begin{array}{l}\text { No effect of } \mathrm{Cd}, \mathrm{Cu} \text { or } \mathrm{Pb} \text { on fish growth. Rainbow } \\
\text { trout growth reduced by As exposure. }\end{array}$ & [42] \\
\hline $\begin{array}{l}\text { Juvenile rainbow trout } \\
(\text { O. mykiss })\end{array}$ & $\begin{array}{l}\text { Diet: Lumbriculus variegates exposed to } 0-8.7 \mathrm{mg} / \mathrm{L} \\
\text { arsenate to result in } 1.6-58 \mu \mathrm{g} / \mathrm{g} \text { As, } 28 \mathrm{~d} \text { exposure at } \\
\text { daily feeding rate of } 40 \mathrm{mg} \text { food/fish. }\end{array}$ & $\begin{array}{l}\text { Growth reduction at the two highest As concentra- } \\
\text { tions }(35-58 \mu \mathrm{g} / \mathrm{g}) \text {. }\end{array}$ & [43] \\
\hline $\begin{array}{l}\text { Seabream } \\
\text { Acanthopagrus } \\
\text { schlegelii }\end{array}$ & $\begin{array}{l}\text { Diet: commercial diets containing } 67-1000 \mu \mathrm{g}(\mathrm{Cu}) / \mathrm{g} \\
\text { with a daily influx rate of } 0.94-7.0 \mu \mathrm{g} / \mathrm{g}, 28 \mathrm{~d} \text { exposure. }\end{array}$ & $\begin{array}{l}\text { Initial reduced consumption rate; specific growth } \\
\text { rate reduced by } 36 \% \text { with a mortality rate of } 8 \% \text { at } \\
\text { the highest } \mathrm{Cu} \text { flux }\left(7.0 \mu \mathrm{g}(\mathrm{Cu}) \mathrm{g}^{-1} \mathrm{~d}^{-1}\right) \text {. }\end{array}$ & [40] \\
\hline $\begin{array}{l}\text { Terapon jurbua } \\
\text { terepon }\end{array}$ & $\begin{array}{l}\text { Daily influx rates of } 0.23-4.7 \mu \mathrm{g}(\mathrm{Cr}) / \mathrm{g}, 2.0-33.4 \mu \mathrm{g} \\
(\mathrm{Fe}) / \mathrm{g}, 0.3-3.3 \mu \mathrm{g}(\mathrm{Cu}) / \mathrm{g}, 2.3-89 \mu \mathrm{g}(\mathrm{Zn}) / \mathrm{g}, 0.06-5.2 \mu \mathrm{g} \\
(\mathrm{As}) / \mathrm{g}, 0.02-5.8 \mu \mathrm{g}(\mathrm{Pb}) / \mathrm{g}, 0.02-0.05 \mu \mathrm{g}(\mathrm{Fe}) / \mathrm{g} ; 21 \mathrm{~d} \\
\text { exposure. }\end{array}$ & & [51] \\
\hline
\end{tabular}

using various endpoints such as growth and feeding rates, metal body burden, subcellular distribution, and MT induction over a period of seven weeks of exposure). During the initial stage of exposure, the abalones' growth and feeding rates were obviously reduced, but the animals then acclimatized. By the end of the experiment feeding and growth had both recovered to the control levels. In the abalones, MT again appeared to be the most useful biomarker. It was induced during the first two weeks of exposure, but levels then decreased. The abalones thus responded rapidly to metal exposure, but subsequently acclimatized.

\section{Considerations in the dietary toxicity testing of metals}

Numerous factors can affect and modify the dietary toxicity of metals, making it rather difficult to compare the results of different toxicity studies (Figure 1). It is also extremely challenging to conduct realistic testing of dietary toxicity of metals in aquatic animals. The first consideration is the partitioning of metals in the medium. In a typical experiment on the toxicity of dietary metals the contaminated food is added to the experimental medium for a period of time. Inevitably, metal from the contaminated food will leach into the water, and the degree of such release will depend on the localization of each metal (e.g., intracellular vs. extracellular), their different partitioning coefficients, as well as the particle load. The partitioning of the metals can be estimated using the following equation.

$$
\text { Metals in the water }(\%)=C_{\mathrm{w}} / C_{\mathrm{t}}=1 /\left(1+K_{\mathrm{d}} \times \mathrm{TSS}\right) \text {, }
$$

where $C_{\mathrm{w}}$ is the dissolved metal concentration, $C_{\mathrm{t}}$ is the total metal concentration in the water, $K_{\mathrm{d}}$ is the partitioning coefficient of the metal concerned, and TSS is the total particle load in the water. 


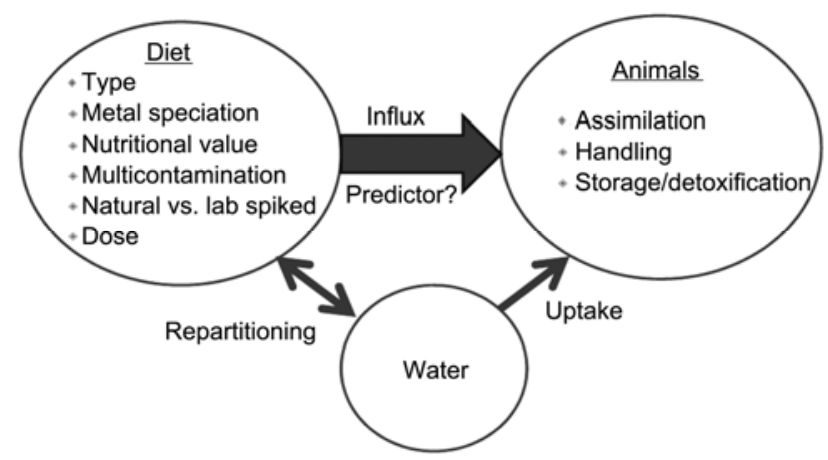

Figure 1 Some of the major considerations in conducting the dietary toxicity of metals to aquatic animals.

Wang and Fisher [11] simulated the changes in metal partitioning as a result of TSS changes. In order to maintain a constant $K_{\mathrm{d}}$, metal partitioning in the particles will decrease with deceasing food concentration. Thus more metal may be repartitioned into the water as the food concentration drops during the exposure period due to the filtering activity of the animals. This is especially true for metals with a high $K_{\mathrm{d}}$ (e.g., $10^{6}$ ), but any change is also dependent on the TSS. At TSS $>4 \mathrm{mg} / \mathrm{L}$ the dependence of metal partitioning on TSS is less obvious. Such simple calculations indicate that any change in food concentration can cause a redistribution of metals between the particles and the dissolved phase. Additionally, metals may also be released from live food as a result of direct exudation (e.g., from algae) [57]. Some metal may subsequently be re-accumulated by the prey during the course of the exposure, but such re-uptake is dependent on the dissolved uptake rate constants of the metals. For some animals such as the predators re-uptake may be negligible due to very low uptake rate constants from the dissolved phase. For other animals such as suspension-feeding zooplankton, re-uptake may be important and contribute the overall accumulation. It is thus critical to at least conduct controlled experiments to examine the release kinetics of the metals concerned and quantify the actual contribution of waterborne uptake to overall metal accumulation.

Another challenging job in studying the dietary toxicity of metals is the choice of prey species. Natural prey are usually preferred, but the question is how "natural" the experimental situation is for the selected prey. One of the intriguing aspects of metal biology is that different invertebrates and possibly phytoplankton have very different strategies for handling and sequestering metals. A classical example is the contrast between mussels and oysters, which exhibit very different bioaccumulation and detoxification potentials in dealing with different metals. Different phytoplankton also have very different bioaccumulation, sequestration and metal tolerance characteristics [58-60]. Currently, most dietary toxicity testing uses standard phytoplankton species (see Table 1), an artificial diet spiked with metals, or natural prey collected from contaminated systems. Differences in metal handling and distribution in different prey may substantially affect the metals' trophic availability to the test animals.

Another complex issue is that predators often feed on a mixture of prey species in natural environments, and there are clear selection processes on different natural prey depending on their relative abundance and the season. The nutritional values of the different prey species should also be considered. Some of the observed toxicological responses may not necessarily be caused by metal stress, but may instead be due to lack of a particular nutrient. In this regard, another side effect to be considered is any depression of the ingestion rate as a result of metal exposure, which may in fact be responsible for a portion of any observed toxicological response.

Generally, the prey or food is exposed to the test metals in solution to prepare the contaminated food before it is offered to the test species. However, the resulting distribution of the metals in the food can be completely different from that in the natural environment. Accumulated metals are known to bind into different subcellular pools. For small prey organisms such as phytoplankton and zooplankton, it may be possible to produce a uniformly spiked prey following a period of exposure. For large prey, laboratory exposure for a short period of time may not achieve metal distribution and speciation comparable to those found in nature. For some metals that are known to be biotransformed (e.g., As, $\mathrm{Hg}, \mathrm{Se}$ ), the final chemical forms in the prey may be different from those in the initial spiked solution or feed. An alternative approach is to use naturally contaminated prey, but that has its own problems. For example, the prey may be contaminated with a suite of metal contaminants, and it is difficult to identify natural prey which have been impacted by just a single metal. Furthermore, there will normally be few choices of natural prey from contaminated environments available. The experimental treatment is thus to a certain extent removed from the control of the experimenter.

Feeding rate is also a major consideration in conducting dietary toxicity tests, and unfortunately this is rarely reported for experiments using zooplankton. Typical toxicity testing often employs high algal food concentrations to promote maximum ingestion activity. For predators such as fish and gastropods it is relatively easy to control the daily feeding rate, but there are obvious differences in this parameter among the different studies reported. Clearwater et al. [35] proposed that the daily dosage rate may be a better predictor of the dietary toxicity of metals than the metal concentration in the diet. In fact, the common practice of simply reporting the metal concentration in the food without the daily dosage rate makes it very difficult to compare the results of different studies. In this regard, a better appreciation of the biokinetics should certainly help in designing toxicity tests. The daily influx rate can be calculated using 
the following equation.

$$
I_{\mathrm{f}}=\mathrm{AE} \times \mathrm{IR} \times C_{\mathrm{f}},
$$

where $I_{\mathrm{f}}$ is the influx rate, $\mathrm{AE}$ is the dietary assimilation efficiency, IR is the ingestion rate of the animals, and $C_{\mathrm{f}}$ is the metal concentration in the food. The daily dosage rate is simply the combination of IR and $C_{\mathrm{f}}$, whereas the daily influx rate also considers the actual amount of metal being assimilated by the animals and it may provide a more realistic measure of the metal's potential dietary toxicity. This parameter may be the basis for inter-comparison of different studies. Thus, simply reporting the $C_{\mathrm{f}}$ in the tested medium will be rather meaningless without knowing the actual amount of metal ingested and bioavailable to the animals. This is exactly analogous to waterborne testing in which the bioavailable metal concentration needs to be known. Very few studies have so far considered the metal influx rate as a predictor of metal dietary toxicity (an exception being that of Dang et al. [40]). Tan and Wang [19] were able to use the influx rate to predict the acute toxicity of $\mathrm{Cd}$ in Daphnia magna at different calcium concentrations. They found the measured median effective influx rate of $\mathrm{Cd}$ (EJ50, 1.3 to $1.6 \mu \mathrm{g} \mathrm{g}^{-1} \mathrm{~h}^{-1}$ ) to be constant as the Ca concentration varied from 0.5 to $200 \mathrm{mg} / \mathrm{L}$.

To conclude, studies of the dietary toxicity of metals are still at an early stage, despite the well-recognized importance of dietary exposure of metals for aquatic animals. Much remains to be learned about the mechanisms of dietary toxicity and their differences from waterborne metal exposure. It is critical that methods be better standardized in conducting toxicity testing, and some new concepts (e.g., influx) need to be introduced in the experimental designs. There is still a long way to go to achieve a somewhat better understanding of the dietary toxicity of metals in aquatic systems. In this regard, we may learn some lessons from the recent significant progress in nanotoxicology.

I thank guest editor Dr. Cai Yong for his invitation to contribute a review article to this special issue. This work was supported by Hong Kong's Research Grants Council (662610 and 663009), and Program for Changjiang Scholars and Innovative Research Team in University (IRT0941).

1 Luoma S N, Johns C, Fisher N S, et al. Determination of selenium bioavailability to a benthic bivalve from particulate and solute pathways. Environ Sci Technol, 1992, 26: 485-492

2 Wang W X, Fisher N S, Luoma S N. Kinetic determinations of trace element bioaccumulation in the mussel, Mytilus edulis. Mar Ecol Prog Ser, 140: 91-113

3 Luoma S N, Fisher N S. Uncertainty in assessing contaminant exposure from sediments. In: Dillon T, Biddinger G, eds. Ecological Risk Assessments of Contaminated Sediments. Pensacola, FL: SETAC Press, 1997. 211-237

4 Wang W X, Fisher N S. Assimilation efficiencies of chemical contaminants in aquatic invertebrates: A synthesis. Environ Toxicol Chem, 1999, 18: 2034-2045

5 Wang W X, Fisher N S. Delineating metal accumulation pathways for aquatic invertebrates. Sci Total Environ, 1999, 237/238: 459-472

6 Wang W X. Incorporating exposure into aquatic toxicological studies:
An imperative. Aquat Toxicol, 2011, 105S: 9-15

7 Meyer J S, Adams W J, Brix K V, et al. eds. Toxicity of Dietborne Metals to Aquatic Organisms. Pensacola FL: SETAC Press, 2005

8 Hook S E, Fisher N S. Reproductive toxicity of metals in calanoid copepods. Mar Biol, 2001, 138: 1131-1140

9 Hook S E, Fisher N S. Sublethal effects of silver in zooplankton: Importance of exposure pathways and implications for toxicity testing. Environ Toxicol Chem, 2001, 20: 568-574

10 Fisher N S, Wang W X. The trophic transfer of silver in marine herbivores: A review of recent studies. Environ Toxicol Chem, 1998, 17: $562-571$

11 Wang W X, Fisher N S. Excretion of trace elements in marine copepods and its bioavailability to diatoms. J Mar Res, 1998, 56: 713729

12 Evens R, De Schamphelaere K A C, Balcaen L, et al. Liposomes as an alternative delivery system for investigating dietary metal toxicity to Daphnia magna. Aquat Toxicol, 2011, 105: 661-668

13 Hook S E, Fisher N S. Relating the reproductive toxicity of five ingested metals in calanoid copepods with sulfur affinity. Mar Environ Res, 2002, 53: 161-174

14 Bielmyer G K, Grosell M, Brix K V. Toxicity of silver, zinc, copper, and nickel to the copepod Acartia tonsa exposed via a phytoplankton diet. Environ Sci Technol, 2006, 40: 2063-2068

15 Lauer M M, Bianchini A. Chronic copper toxicity in the estuarine copepod Acartia tonsa at different salinities. Environ Toxicol Chem, 2010, 29: 2297-2303

16 De Schamphelaere K A C, Janssen C R. Effects of chronic dietary copper exposure on growth and reproduction of Daphnia magna. Environ Toxicol Chem, 2004, 23: 2038-2047

17 De Schamphelaere K A C, Forrez I, Dierckens K, et al. Chronic toxicity of dietary copper to Daphnia magna. Aquat Toxicol, 2007, 81: 409-418

18 Wang Z S, Kong H N, Wu D Y. Reproductive toxicity of dietary copper to a saltwater cladoceran, Moina monogolica Daday. Environ Toxicol Chem, 2007, 26: 126-131

19 Tan Q G, Wang W X. Acute toxicity of cadmium in Daphnia magna under different calcium and $\mathrm{pH}$ conditions: Importance of influx rate. Environ Sci Technol, 2011, 45: 1970-1976

20 Kolts J M, Boese C J, Meyer J S. Effects of dietborne copper and silver on reproduction by Ceriodaphnia dubia. Environ Toxicol Chem, 2009, 28: 71-85

21 Sofyan A, Price D J, Birge W J. Effects of aqueous, dietary and combined exposures of cadmium to Ceriodaphnia dubia. Sci Total Environ, 2007, 385: 108-116

22 Sofyan A, Rosita G, Price D J, et al. Cadmium uptake by Ceriodaphnia dubia from different exposures: Relevance to body burden and toxicity. Environ Toxicol Chem, 2007, 26: 470-477

23 Geffard O, Geffard A, Chaumot A, et al. Effects of chronic dietary and waterborne cadmium exposures on the contamination level and reproduction of Daphnia magna. Environ Toxicol Chem, 2008, 27: 1128-1134

24 Wang Z S, Yan C Z, Hyne R V. Effects of dietary cadmium exposure on reproduction of saltwater cladoceran Moina monogolica Daday: Implications in water quality criteria. Environ Toxicol Chem, 2010, 29: $365-372$

25 Zhao C M, Wang W X. Comparison of acute and chronic toxicity of silver nanoparticles and silver nitrate to Daphnia magna. Environ Toxicol Chem, 2011, 30: 885-892

26 Evens R, De Schamphelaere K A C, Janssen C R. The effects of dietary nickel exposure on growth and reproduction of Daphnia magna. Aquat Toxicol, 2009, 94: 138-144

27 De Schamphelaere K A C, Canli M, Van Lierde V, et al. Reproductive toxicity of dietary zinc to Daphnia magna. Aquat Toxicol, 2004, 70: 233-244

28 Canli M. Dietary and water-borne $\mathrm{Zn}$ exposures affect energy reserves and subsequent $\mathrm{Zn}$ tolerance of Daphnia magna. Comp Biochem Physiol C, 2005, 141: 110-116

29 Handy R D. The effect of acute exposure to dietary $\mathrm{Cd}$ and $\mathrm{Cu}$ on organ toxicant concentrations in rainbow trout Oncorhynchus mykiss. 
Aquat Toxicol, 1993, 27: 1-14

$30 \mathrm{Ng} \mathrm{T} \mathrm{Y} \mathrm{T}$, Wood C M. Trophic transfer and dietary toxicity of $\mathrm{Cd}$ from the oligochaete to the rainbow trout. Aquat Toxicol, 2008, 87: 47-59

31 Mount D R, Barth A K, Garrison T D, et al. Dietary and waterborne exposure of rainbow trout (Oncorhynchus mykiss) to copper, cadmium, lead and zinc using a live diet. Environ Toxicol Chem, 1994, 13: 2031-2041

32 Lundebye A K, Berntssen M H G, Bonga W S E, et al. Biochemical and physiological responses in Atlantic Salmon (Salmo salar) following dietary exposure to copper and cadmium. Mar Pollut Bull, 1999, 39: 137-144

33 Berntssen M H G, Aspholm O $\varnothing$, Hylland K, et al. Tissue metallothionein, apoptosis and cell proliferation responses in Atlantic salmon (Salmo salar L.) parr fed elevated dietary cadmium. Comp Biochem Physiol C, 2001, 128: 299-310

34 Berntssen M H G, Lundebye A K. Energetics in Atlantic salmon (Salmo salar L.) parr fed elevated dietary cadmium. Comp Biochem Physiol C, 2001, 128: 311-323

35 Clearwater S J, Farag A M, Meyer J S. Bioavailability and toxicity of dietborne copper and zinc to fish. Comp Biochem Physiol C, 2002, 132: 269-313

36 Galvez F, Hogstrand C, McGeer J C, et al. The physiological effects of a biologically incorporated silver diet on rainbow trout (Oncorhynchus mykiss). Aquat Toxicol, 2001, 55: 95-112

37 Ptashynski M D, Pedlar R M, Evans R E. Toxicology of dietary nickel in lake whitefish (Coregonus clupeaformis). Aquat Toxicol, 2002, 58: 229-247

38 Dang F, Wang W X. Assessment of tissue-specific accumulation and effects of cadmium in a marine fish fed contaminated commercially produced diet. Aquat Toxicol, 2009, 95: 248-255

39 Tan X Y, Luo Z, Zhang G Y, et al. Effect of dietary cadmium level on the growth, body composition and several hepatic enzymatic activities of juvenile yellow catfish, Pelteobagrus fulvidraco. Aquacult Res, 2010, 41: 1022-1029

40 Dang F, Wang W X, Rainbow P S. Unifying prolonged copper exposure, accumulation, and toxicity from food and water in a marine fish. Environ Sci Technol, 2012, 46: 3465-3471

41 Hansen J A, Lipton J, Welsh P G, et al. Reduced growth of rainbow trout (Oncorhynchus mykiss) fed a live invertebrate diet pre-exposed to metal-contaminated sediments. Environ Toxicol Chem, 2004, 23: 1902-1911

42 Erickson R J, Mount D R, Highland T L, et al. Effects of copper, cadmium, lead, and arsenic in a live diet on juvenile fish growth. Can J Fisher Aquat Sci, 2010, 67: 1816-1826

43 Erickson R J, Mount D R, Highland T L, et al. The relative importance of waterborne and dietborne arsenic exposure on survival and growth of juvenile rainbow trout. Aquat Toxicol, 2011, 104: 108-115

44 Zhang W, Huang L M, Wang W X. Biotransformation and detoxification of inorganic arsenic in a marine juvenile fish Terapon jarbua after waterborne and dietary exposure. J Hazard Mater, 2012, 221/222: $162-169$
45 Zhang W, Huang L M, Wang W X. Arsenic bioaccumulation in a marine juvenile fish Terapon jarbua. Aquat Toxicol, 2011, 105: 582-588

46 Khan F R, Bury N R, Hogstrand C. Cadmium bound to metal rich granules and exoskeleton from Gammarus pulex causes increased gut lipid peroxidation in zebrafish following single dietary exposure. Aquat Toxicol, 2010, 96: 124-129

47 Khan F R, Bury N R, Hogstrand C. Differential uptake and oxidative stress response in zebrafish fed a single dose of the principal copper and zinc enriched sub-cellular fractions of Gammarus pulex. Aquat Toxicol, 2010, 99: 466-472

48 Boyle D, Brix K V, Amlund H, et al. Natural arsenic contaminated diets perturb reproduction in fish. Environ Sci Technol, 2008, 42: 5354-5360

49 Boyle D, Amlund H, Lundebye A K, et al. Bioavailability of a natural lead-contaminated invertebrate diet to zebrafish. Environ Toxicol Chem, 2010, 29: 708-714

50 Boyle D, Hogstrand C, Bury N R. Physiological response to a metalcontaminated invertebrate diet in zebrafish: Importance of metal speciation and regulation of metal transport pathways. Aquat Toxicol, 2011, 105: 21-28

51 Dang F, Rainbow P S, Wang W X. Dietary toxicity of field-contaminated invertebrates to marine fish: Effects of metal doses and subcellular metal distribution. Aquat Toxicol, 120/121: 1-10

52 Besser J M, Brumbaugh W G, Brunson E L, et al. Acute and chronic toxicity of lead in water and diet to the amphipod Hyalella azteca. Environ Toxicol Chem, 2005, 24: 1807-1815

53 Ball A L, Borgmann U, Dixon D G. Toxicity of a cadmium-contaminated diet to Hyalella azteca. Environ Toxicol Chem, 2006, 25: 2526-2532

54 Golding L A, Borgmann U, Dixon D G. Modeling chronic dietary cadmium bioaccumulation and toxicity from periphyton to Hyalella azteca. Environ Toxicol Chem, 2011, 30: 1709-1720

55 Cheung M S, Fok E M W, Ng T Y T, et al. Subcellular cadmium distribution, accumulation, and toxicity in a predatory gastropod, Thais clavigera, fed different prey. Environ Toxicol Chem, 2006, 25: 174-181

56 Huang X, Guo F, Ke C H, et al. Responses of abalone Haliotis diversicolor to sublethal exposure of waterborne and dietary silver and cadmium. Ecotoxicol Environ Safety, 2010, 73: 1130-1137

57 Zhang W, Wang W X. Production of colloidal organic carbon and trace metal $(\mathrm{Cd}, \mathrm{Fe}$, and $\mathrm{Zn})$ by diatom exudation and copepod grazing. J Exp Mar Biol Ecol, 2004, 307: 17-34

58 Miao A J, Wang W X, Juneau P. Comparison of $\mathrm{Cd}, \mathrm{Cu}$, and $\mathrm{Zn}$ toxic effects on four marine phytoplankton by PAM fluorometry. Environ Toxicol Chem, 2005, 24: 2603-2611

59 Wang M J, Wang W X. Cadmium in three marine phytoplankton: Accumulation, subcellular fate and thiol induction. Aquat Toxicol, 2009, 95: 99-107

60 Wu Y, Wang W X. Accumulation, subcellular distribution and toxicity of inorganic mercury and methylmercury in marine phytoplankton. Environ Pollut, 2011, 159: 3097-3105

Open Access This article is distributed under the terms of the Creative Commons Attribution License which permits any use, distribution, and reproduction in any medium, provided the original author(s) and source are credited. 